\begin{tabular}{|c|c|}
\hline $\begin{array}{l}\text { Jurnal Pakarena } \\
\text { Volume } 3 \text { Nomor 2, Desember } 2018 \\
\text { e-ISSN: 2550-102X dan p-ISSN: 1693-3990 }\end{array}$ & PAKARENA \\
\hline $\begin{array}{l}\text { (c) This work is licensed under a Creative Commons Attribution } \\
4.0 \text { International License }\end{array}$ & : \\
\hline
\end{tabular}

\title{
KESENIAN MA'RONGGENG DI DESA PAROMBEAN KABUPATEN ENREKANG
}

\section{Hamrin; Anggita}

Keywords :

Kata Kunci; ma'ronggeng, kesenian tradisional, barutung.

\section{Corespondensi Author}

Pendidikan Sendratasik Fakultas

Seni dan Desain Universitas

Negeri Makassar

hamrin@unm.ac.id

\begin{abstract}
ABSTRAK
Penelitian ini mengangkat masalah tentang bagaimana latar belakang kesenian ma'ronggeng serta fungsi kesenian ma'ronggeng di Desa Parombean Kabupaten Enrekang. Penelitian ini bertujuan untuk mengetahui latar belakang kesenian ma'ronggeng di Desa Parombean Kabupaten Enrekang serta fungsi kesenian ma'ronggeng di Desa Parombean Kabupaten Enrekang. Metode yang digunakan adalah dengan pendekatan kualitatif, sedangkan pengumpulan data dengan teknik observasi, wawancara dan dokumentasi. Berdasarkan penelitian, diperoleh hasil sebagai berikut: Jauh sebelum islam masuk di Parombean, barutung atau bambu yang biasa disebut suke oleh masyarakat sekitar, digunakan sebagai media penghubung dalam ritual penolak bala kepada dewata. Barutung yang hadir pada setiap sendi kehidupan masyarakat Parombean, secara alami mengekspresikan karya kesenian yang menjadi kultur dalam masyarakatnya. Sejarah kesenian ma'ronggeng berawal dari kebiasaan masyarakat sekitar yang mengantri menunggu giliran mengambil air pada satu-satunya sumber mata air di Desa Parombean. Aktivitas ketika menunggu air adalah menghentak-hentakkan bambu panjang yang disebut lampa dan pongke yang kemudian menimbulkan ide dan gagasan untuk menjadikannya sebuah kesenian tradisional. Lampa, pongke, dan suke digabungkan sehingga menghasilkan bunyi khas bambu yang kemudian dinamai dengan kesenian ma'ronggeng atau ma'barutung. Adapun 4 fungsi kesenian ma'ronggeng di Desa Parombean yaitu fungsi hiburan, fungsi komunikasi, fungsi ritual, danfungsi pengintegrasian masyarakat.
\end{abstract}

\footnotetext{
ABSTRACT

This study raises the problem of how the background of ma'ronggeng art and the function of ma'ronggeng art in Parombean Village, Enrekang RegencyThis study aims to determine the background of ma'ronggeng art in Parombean Village, Enrekang Regency and the function of ma'ronggeng art in Parombean Village, Enrekang Regency. The method used is a qualitative approach, while data collection by observation, interview and documentation techniques. Based on the research, the following results were obtained: Long before Islam entered the Parombean, barutung or bamboo which is commonly called suke by the
} 
Hamrin; Angraeni. Kesenian Ma'ronggeng Di Desa Parombean Kabupaten Enrekang

\begin{abstract}
surrounding community, was used as a connecting medium in the ritual of repelling reinforcements to the gods. Barutung who is present at every aspect of the life of the Parombean community, naturally expresses the work of art that has become a culture in their society. The history of the ma'ronggeng art begins with the custom of the surrounding community who are waiting in line to wait for their turn to take water at the only source of water in the Parombean Village. Activities while waiting for water is stomping long bamboo called lampa and pongke which then gives rise to ideas and ideas to make it a traditional art. Lampa, pongke, and suke are combined to produce a distinctive sound of bamboo which is then named with the art ma'ronggeng or ma'barutung. The 4 functions of ma'ronggeng art in Parombean Village are the entertainment function, communication function, ritual function, and community integration function..
\end{abstract}

\section{PENDAHULUAN}

Kesenian adalah bagian dari budaya yang merupakan sarana yang digunakan untuk mengekspresikan rasa keindahan dari dalam jiwa manusia. Selain itu kesenian juga memiliki berbagai fungsi dalam masyarakat yang ditinjau dari kebutuhan zamannya. Kesenian dapat berfungsi sebagai upacara keagamaan, hiburan, ilmu pengetahuan, maupun mata pencaharian. Dengan melihat berbagai fungsinya, maka masyarakat merasa butuh dengan kesenian, ini merupakan alasan mengapa kesenian masih hadir ditengahtengah masyarakat hingga dalam kondisi globalisasi yang semakin berkembang. Hampir disetiap daerah pada setiap provinsi di Indonesia masih menjaga keseniannya sehingga tetap bisa menjadi ciri khas dari dari daerah tersebut.

Sulawesi Selatan merupakan salah satu provinsi di Indonesia dengan kebudayaan dan kesenian yang beragam. Seperti halnya kesenian seperti musik tradisional, tidak jarang kita jumpai diberbagai kabupaten di Sulawesi Selatan. Sama halnya di daerah lain, Sulawesi Selatan hingga saat ini masih melestarikan kesenian-kesenian hasil karya tau jolo atau orang-orang dulu yang karyanya masih bisa dijumpai meskipun ada yang sudah mulai jarang dipertunjukkan di depan umum.
Musik diciptakan sebagai media untuk mengekspresikan perasaan seseorang atau pesan maupun kesan yang akan diungkapkan. Dengan begitu, Musik tidak pernah terlepas dari masyarakat pendukungnya. Mereka menciptakan musiknya sendiri untuk mengekspresikan semuanya berdasarkan kehidupannya sehari-hari, mengungkapkan kondisi sosial dalam masyarakat, juga sebagai sarana ritual bagi yang masyarakatnya masih kental akan budaya dan tradisi.

Kabupaten Enrekang adalah salah satu daerah di Sulawesi Selatan yang mayoritas penduduknya beretnis suku Bugis, mereka sehari hari menggunakan bahasa Bugis juga bahasa duri. Selain terkenal dengan pariwisata dan keseniannya, Kabupaten Enrekang juga begitu dikenal dengan semboyan massenrempulu yang artinya pemukiman di bawah kaki-kaki pegunungan yang di dalamnya terdiri dari etnik Bugis dan Toraja. Tepatnya di Kecamatan Curio Kabupaten Enrekang, masyarakat masih melestarikan adat istiadat. Seperti kehidupan di desa pada umumnya, desa Parombean juga masih melaksanakan upacara-upacara tradisional seperti pesta panen, pernikahan, acara sunatan, dan acara-acara lainnya yang masih menampilkan kesenian khas daerah tersebut seperti musik bambu bas dan ma'ronggeng. 
Berdasarkan observasi awal yang telah peneliti lakukan, Ma'ronggeng merupakan salah satu jenis permainan musik khas daerah Enrekang yang menggunakan berbagai jenis bambu yaitu lampa, pongke, dan suke yang merupakan sumber bunyi dalam kesenian ini. Namun, ada sedikit perbedaan dengan musik bambu bas, yaitu musik bambu bas yang merupakan permainan musik bambu khas Enrekang menggunakan alat musik yang berbeda - beda meskipun semuanya terbuat dari potongan bambu. Jika dilihat dari cara memainkannya, musik bambu bas dimainkan dengan cara ditiup, sedangkan ma'ronggeng hanya menggunakan alat yang berupa bambu yang bentuknya semua sama hanya ukuran yang berbeda-beda, jika dilihat dari cara memainkannya, alat musik yang digunakan dihentak - hentakkan ke tanah. Selain menggunakan alat bambu yaitu suke, pongke, dan lampa dalam bahasa parombean, dalam permainan ma'ronggeng juga digunakan alat musik gendang dan krincing sebagai pelengkap.

Di Desa Parombean, Ma'ronggeng merupakan bentuk kesenian yang menggunakan bambu atau barutung yang dimainkan oleh wanita dan pria. Dalam pertunjukannya, seorang pak palu ( dirigen ) dipercayakan untuk mengatur jalannya pertunjukan musik agar tetap selaras. Saat ini, desa Parombean menjadi satu-satunya desa di Kabupaten Enrekang yang masih mempertahankankesenian ma'ronggeng.

Kesenian ma'ronggeng hanya lebih diketahui dan berkembang dalam wilayah Kecamatan Curio khususnya di Desa Parombean saja. Dalam hal ini, sangat di sayangkan bila kesenian ma'ronggeng yang merupakan kesenian warisan leluhur di Kabupaten Enrekang perkembangannya hanya di Desa Parombean. Jika dilihat dari fungsinya, kesenian ma'ronggeng mulai jarang dipentaskan di acara adat khususnya pernikahan dan sudah mulai digantikan oleh hiburan yang sifatnya lebih modern seperti organ tunggal dan orkes yang lebih kekinian.
Berdasarkan hal di atas maka peneliti merasa penting untuk melakukan penelitian terhadap kesenian ma'ronggeng karena kesenian Ma'ronggeng merupakan salah satu kesenian tradisional yang ada di Sulawesi Selatan yang memang harus dipertahankan dan dikembangkan sehingga lebih banyak masyarakat mengetahui kesenian ma'ronggeng itu sendiri. Selain itu peneliti memilih kesenian ma'ronggeng untuk diteliti karena sebelumnya belum pernah ada yang melakukan penelitian terhadap kesenian ma'ronggeng.

\section{B. Rumusan Masalah}

Berdasarkan latar belakang masalah di atas, adapun rumusan masalah dari kesenian ma'ronggeng di desa Parombean Kabupaten Enrekang adalah sebagai berikut :

1. Bagaimana latar belakang kesenian ma'ronggeng di Desa Parombean Kabupaten Enrekang?

2. Bagaimana fungsi kesenian ma'ronggeng di Desa Parombean Kabupaten Enrekang?

\section{Tujuan Penelitian}

Adapun tujuan dari penelitian kesenian ma'ronggeng di desa Parombean Kabupaten Enrekang adalah sebagai berikut :

1. Mendeskripsikan latar belakang kesenian ma'ronggeng di Desa Parombean Kabupaten Enrekang.

2. Mendeskripsikan fungsi kesenian ma'ronggeng di Desa Parombean Kabupaten Enrekang

\section{KAJIAN PUSTAKA}

\section{A.Tinjauan Pustaka}

\section{Penelitian Terdahulu}

Penelititan terdahulu yang dilakukan oleh Ika Mustika Batara Randa (2016) yang berjudul "Musik Bambu (Bas) dalam Acara Pesta Panen di Masyarakat Desa Tallung Ura' Kabupaten Enrekang”.

Adapun perbedaan antara penelitian relevan dengan penelitian yang akan 
Hamrin; Angraeni. Kesenian Ma'ronggeng Di Desa Parombean Kabupaten Enrekang

dilaksanakan yaitu penelitian relevan memilih lokasi di Desa Tallung Ura' Kabupaten Enrekang dan fokus penelitian pada acara pesta panen sedangkan penelitian yang akan dilaksanakan di Desa Parombean Kabupaten Enrekang. Selanjutnya, persamaan antara penelitian relevan dengan penelitian yang akan dilaksanakan adalah menggunakan bambu sebagai objek penelitian.

Hasil analisis dari penelitian yang relevan yaitu bentuk penyajian musik bambu(bas) dalam acara pesta panen di masyarakat Desa Tallung Ura' kabupaten Enrekang adalah pertunjukan musik bambu(bas) dilaksanakan pada siang hari, pemusik berkisar antara 3040 orang termasuk dirigen, sistem tangga nada yang digunakan yaitu sistem tangga nada diatonis mayor dan kostum yang digunakan biasanya memakai pakaian yang sopan seperti batik. Fungsi musik bambu(bas) dalam acara pesta panen sebagai media pemersatu dan hiburan bagi masyarakat yang beraktivitas di sawah. Selain itu juga, fungsi musik bambu adalah sebagai sarana untuk masyarakat tetap menjaga dan melestarikan musik bambu(bas) sebagai suatu aset budaya di kabupaten Enrekang yang tidak ternilai dan merupakan salah satu aset kekayaan budaya Indonesia

\section{Kesenian.}

Perkembangan kesenian tradisional mengandung pengertian bahwa ada alasanalasan untuk mempertahanlan kesenian tradisional tetapi jelas tidak semata-mata dengan menjadikannya barang mati. Suatu hal lain yang membuat mempertahankan kesenian tradisional adalah kenyataan adanya pengaruh dari luar tradisi yang memunculkan terjadinya perubahan pada kesenian tersebut, sehingga yang patut diusahakan adalah untuk membuat tradisi-tradisi kesenian itu tidak kehilangan hidupnya, dan untuk senantiasa membuat iklim dalam mewujudkan aspirasi manusia seniman atau inspirasi masyarakat.

\section{Musik Bambu}

Musik bambu adalah alat tiup yang hanya menghasilkan satu nada saja dan mempunyai jajahan nada satu oktaf, Kasenda, E (1840) dalam (Buchary, 2008:9). Sedangkan Ali, M (1989) dalam (Buchary, 2008:19) menyatakan bahwa musik bambu adalah alat tiup yang mengeluarkan satu nada yang terbuat dari tabung bambu.

Terlepas dari pengertian musik bambu di atas, namun ditemukan juga kesenian musik bambu yang cara membunyikannya tidak dengan ditiup. Ada yang dimainkan dengan cara dipukul, ada yang di getarkan seperti angklung, dan ada pula yang dihentakhentakkan ke tanah seperti musik ronggeng.

\section{Musik Tradisional}

Musik tradisional merupakan musik yang hidup dimasyarakat secara turun temurun yang dipertahankan sebagai sarana hiburan. Tiga komponen yang saling memengaruhi diantaranya seniman, musik itu sendiri, dan masyarakat penikmatnya. Menurut Kamus Besar Bahasa Indonesia (Depdikbud 1988:959) Tradisional memiliki pengertian "sikap dan cara berfikir serta bertindak yang selalu berpegang teguh pada norma yang ada secara turun temurun".

Musik daerah atau musik tradisional adalah musik yang selalu lahir dan berkembang diberbagai daerah di Indonesia. Ciri khas pada jenis musik tersebut terletak pada isi instrumen lagu (alur musiknya). Seni tradisi yang merupakan salah satu lambang atau simbolis identitas, jati diri, media ekspresi dari masyarakat pendukungnya. Musik tradisi memiliki karakteristik khas, yakni syair dan melodinya menggunakan syair dan gaya kedaerahan.

\section{Fungsi musik}

Penciptaan suatu karya seni selalu memiliki tujuan. Secara garis besar tujuan itu bisa dikelompokkan menjadi tiga, yaitu : (1) seni untuk tujuan ritual: (2) seni untuk tujuan persentasi estetis: dan (3) seni sebagai hiburan pribadi ( Soedarsono 1999: 1 - 2 ) dalam S. Suharto : 1

Merriam dalam bukunya The Antropologhy of Music (1964 : 218) menyatakan ada 10 fungsi dari musik, yaitu ;

1) Fungsi pengungkapan emosional, disini musik berfungsi sebagai suatu 
media bagi seseorang untuk mengungkapkan suatu perasaan atau emosinya. Dengan kata lain, si pemain dapat mengungkapkan perasaan atau emosinya melalui musik.

2) Fungsi penhayatan estetis. Musik merupakan suatu karya seni. Suatu karya dapat dikatakan karya seni apabia dia memiliki unsur keindahan atau estetika didalamnya. Melalui musik kita dapat merasakan nilai nilai keindahan baik melalui melodi maupun dinamikanya.

3) Fungsi hiburan. Musik memiliki fungsi hiburan, mengacu kepada pengertian bahwa semua musik pasti mengandung unsur- unsur yang bersifat menghibur. Hal ini dapat dinilai dari melodi maupun liriknya.

4) Fungsi komunikasi. Musik memiliki fungsi komunikasi yang berarti bahwa senuah musik yang berlaku disuatu daerah kebudayaan mengandung isyarat - isyarat tersendiri yang hanya diketahui oleh masyarakat pendukung kebudayaan tersebut. Hal ini dapat dilihat dari lirik maupun melodi dari daerah tersebut.

5) Fungsi perlambangan. Musik memiliki fungsi dalam melambangkan suatu hal. Hal ini dapat dilihat dari aspek - aspek musik tersebut, misalnya pada tempo. Jika tempo dari sebuah musik itu lambat, maka kebanyakan liriknya menceritakan hal yang sedih. Sehingga musik tersebut melambangkan atau menggambarkan tentang kesedihan.

6) Fungsi reaksi jasmani. Apabila sebuah musik dimainkan, musik tersebut dapat merangsang sel-sel saraf manusia sehingga dapat menyebabkan tubuh kita bergerak mengikuti irama dan musik itu sendiri. Jika musik yang dimainkan cepat maka gerakan kita cepat juga, dan sebaliknya.

7) Fungsi yang berkaitan dengan norma sosial, musik berfungsi sebagai media pengajaran akan norma - norma atau pengaturan - $\quad$ pengaturan. Penyampaian kebanyakan melalui lirik dalam nyanyian yang berisi peraturan.

8) Fungsi pengesahan lembaga sosial. Fungsi musik disini berarti bahwa sebuah musik memiliki peranam yang sangat penting dalam suatu upacara, bukan hanya sebagai pengiring.

9) Fungsi kesinambungan budaya. Fungsi ini hampir sama dengan fungsi yang berkaitan dengan norma sosial. Dalam hal ini, musik berisi tentang ajaran-ajaran untuk meneruskan sebuah sistim dalam kebudayaan kepada generasi selanjutnya.

10) Fungsi pengintegrasian masyarakat. Musik memiliki fungsi dalam pengintegrasian dalam masyarakat. Suatu musik yang dimainkan secara bersama-sama tanpa disadari dapat menimbulkan kebersamaan diantara pemain dan penikmat dari musik tersebut.

\section{METODE PENELITIAN}

\section{A. Jenis penelitian}

\section{Jenis Penelitian}

Berdasarkan metodenya, penelitian ini merupakan penelitian kualitatif. Penelitian kualitatif merupakan penelitian yang mengamati orang dalam lingkungan sekitar, berinteraksi dengan mereka, memahami bahasa dan tafsiran mereka.

\section{B. Defenisi Operasional Variabel}

Variabel dalam penelitian ini didefenisikan sebagai berikut :

1. Latar belakang kesenian Ma'ronggeng dalam penelitian adalah dimana peneliti menjelakan mengenai kesenian Ma'ronggeng di Desa Parombean kabupaten Enrekang. Dalam hal ini, latar belakang yang dimaksud termasuk sejarah dari kesenian Ma'ronggeng di Desa Parombean Kabupaten Enrekang.

2. Fungsi kesenian Ma'ronggeng di desa Parombaen kabupaten Enrekang. Dalam hal ini, variabel menyangkut tentang apa saja yang menjadi fungsi kesenian 
Hamrin; Angraeni. Kesenian Ma'ronggeng Di Desa Parombean Kabupaten Enrekang

Ma'ronggeng di desa Parombean Kabupaten Enrekang. Adapun fungsi yang dimaksud adalah fungsi hiburan, fungsi pengintegrasian masyarakat, fungsi ritual, dan fungsi komunikasi.

\section{Sasaran dan Lokasi Penelitian}

1. Sasaran penelitian

Sasaran dalam penelitian ini adalah kesenian Ma'ronggeng di desa Parombean kabupaten Enrekang dalam artian menjelaskan mengenai kesenian tersebut. Adapun yang menjadi Informan dalam penelitian ini tak lain adalah masyarakat dari desa Parombean, diantaranya para pa'ronggeng atau orang-orang yang selama ini ikut serta dalam kesenian Ma'ronggeng serta warga di desa tersebut yang hingga saaat ini masih menjaga keberadaan kesenian Ma'ronggeng.

2. Lokasi Penelitian

Penelitian ini mengambil lokasi di Desa Parombean Kecamatan Curio Kabupaten Enrekang Provinsi Sulawesi Selatan

\section{Teknik Pengumpulan Data}

\section{Observasi}

Teknik observasi merupakan pengamatan terhadap suatu kegiatan dengan pemusatan perhatian terhadap suatu objek. observasi adalah studi yang sengaja dilaksanakan secara sistematis, terencana, terarah pada suatu kajian dengan mengamati dan mencatat fenomena dan perilaku sesuatu atau sekelompok orang dalam kehidupan seharihari dan memperlihatkan syarat-syarat penelitian ilmiah.

2.Wawancara

Dalam penelitian dilakukan proses wawancara untuk mendapatkan informasi atau keterangan secara lisan mengenai latar belakang dan fungsi kesenian ma'ronggeng di Desa Parombean kaabupaten Enrekang. Wawancara dilakukan secara bertahap dan terbuka, dibantu dengan alat perekam dan semacamnya untuk mengantisipasi agar pewawancara tidak lupa dengan apa yang telah dipaparkan oleh orang yang diwawancarai.

3. Dokumentasi
Penulis menampilkan dokumen dari Kesenian Ma'ronggeng itu sendiri. Tujuannya adalah dokumen-dokumen tersebut dapat diuraikan penulis dalam hasil penelitiannya agar menjadi suatu bukti yang merupakan bukti yang sah dari hasil penelitiannya, serta dapat memperkuat proses penelitian yang benar-benar dilakukan.

\section{E. Teknik Analisis Data}

Adapun langkah-langkah yang digunakan dalam analisis data yaitu :

1. Reduksi data

2. Penyajian data

3. Mengambil kesimpulan dan verifikasi

\section{HASIL PENELITIAN DAN PEMBAHASAN}

\section{A. Hasil Penelitian}

\section{Profil Desa Parombean}

Desa Parombean berada pada wilayah Kecamatan Curio Kabupaten Enrekang. Desa Parombean menjadi pembatas antara Kabupaten Enrekang dan Kabupaten Toraja, itulah sebabnya bahasa dan perilaku kehidupan masyarakatnya memiliki kesamaan dengan masyarakat Toraja pinggiran. Desa Parombean merupakan desa yang menjadi tempat penelitian dari kesenian ma'ronggeng. Untuk menuju ke Desa Parombean, dibutuhkan waktu tempuh sekitar 1 jam 30 menit dari jalan poros EnrekangToraja.

Di setiap daerah disuatu wilayah masing-masing memiliki karakteristik agraris yang berbeda, salah satunya adalah di Desa Parombean yang terkenal dengan karakteristik bambu yang tumbuh subur dan menjadi bagian penting yang tidak bisa terlepas dari kehidupan masyarakatnya sehingga nyaris setiap perilaku kehidupan mereka senantiasa bersentuhan dengan bambu. Bambu adalah tanaman dengan laju pertumbuhan terbilang cepat khususnya di daerah yang beriklim dingin pegunungan. Seperti yang diketahui, Desa Parombean merupakan desa yang berada pada wilayah 
pegunungan Enrekang yang memiliki iklim dingin sehingga pertumbuhan tanaman bambu di daerah ini dari waktu ke waktu selalu mengalami perkembangan. Kondisi ini menjadikan masyarakat Desa Parombean sejak dulu memanfaatkan bambu untuk kepentingan hidup mereka, seperti bambu atau barutung yang di gunakan sebagai bahan utama untuk membuat rumah, membuat lumbung padi, lumbung air, maupun perabotan rumah tangga.

Begitu kuatnya mitos kedekatan masyarakat Desa Parombean dengan bambu atau barutung menjadikan kepercayaan terhadap bambu sebagai bagian penting dalam kultur masyarakat Parombean yang begitu kuat dan telah mengakar sejak dahulu, jauh sebelum masuknya ajaran islam di Sulawesi Selatan. Barutung yang hadir dalam setiap sendi kehidupan masyarakat Parombean, secara alami mengekspresikan berbagai karya kesenian dan menjadi kultur masyarakatnya sejak dulu sehingga tanpa sadar bahwa sesungguhnya sebuah ekspresi kesenian telah mereka ciptakan.

\section{Latar Belakang Kesenian Ma'ronggeng di Desa Parombean Kabupaten Enrekang}

Latar belakang sejarah kesenian ma'ronggeng di Desa Parombean Kecamatan Curio dikisahkan berawal dari kehidupan masyarakat di desa tersebut. Hutan bambu yang diwariskan nenek moyang mereka telah memberikan banyak manfaat kehidupan. Bambu atau yang lebih dikenal dengan nama barutung menjadi salah satu kebutuhan pokok masyarakat sejak saat itu. ( Wawancara Sulaiman 13 Agustus 2019)

Jauh sebelum zaman berkembang, pengolahan barutung masih terbilang sederhana, dimana masyarakat harus menunggu pohon bambu yang di tanam tumbuh besar, setelah itu masyarakat harus kembali menunggu pohon bambu yang sudah besar dan menua tumbang dengan sendirinya. Tidak hanya sampai disitu, setelah tumbang masyarakat kembali harus menunggu bambu tersebut hingga mengering agar mudah untuk dipatahkan dan dibentuk. Namun setelah berada pada zaman dimana sudah ada besi seperti parang dan gergaji yang dapat mempermudah kehidupan sehari hari, barutung diolah dan dibentuk oleh tangan manusia sesuai dengan kebutuhan. Sejak saat itu pula barutung dibuat dalam beberapa bentuk yang saat ini digunakan dalam kesenian ma'ronggeng. (Wawancara Sulaiman 13 Agustus 2019)

\section{B. Pembahasan}

\section{Latar Belakang Kesenian Ma'ronggeng di Desa Parombean Kabupaten Enrekang}

Latar belakang sejarah merupakan salah satu tolak ukur untuk dapat menjelaskan dan membuktikan tentang keberadaan suatu kesenian. Dalam Kamus Besar Bahasa Indonesia Pusat Bahasa (2008:6) kata ada artinya hadir, telah sedia, mempunyai, benar, sungguh. Sedangkan keberadaan adalah suatu kehadiran atau hal yang berada.

Salah satu yang menjadi kekayaan Kabupaten Enrekang adalah dari segi kesenian tradisionalnya di mana kesenian tradisional di daerah Enrekang merupakan kekayaan yang secara turun-temurun diwariskan kepada masyarakatnya. Pemahaman tersebut sejalan dengan yang dikemukakan oleh ( Yoety, 1983: 13) dalam ( Fauzan Rikza 2017 : 2) yang mengatakan bahwa kesenian tradisional adalah kesenian yang sejak lama hidup dan berkembang pada suatu daerah, masyarakat etnik tertentu yang perwujudannya mempunyai peranan tertentu dalam masyarakat pendukungnya.

Kesenian ma'ronggeng adalah salah satu dari sekian banyak kekayaan kesenian tradisional di Kabupaten Enrekang 
Hamrin; Angraeni. Kesenian Ma'ronggeng Di Desa Parombean Kabupaten Enrekang

tepatnya di Desa Parombean. Kesenian ma'ronggeng adalah kesenian musik tradisional yang berkembang di tengahtengah masyarakat dan bukan merupakan kesenian yang dikhususkan untuk kalangan kerajaan. Seperti yang dikemukakan oleh M. Ramdhan Adhi dalam bukunya mengenal musik tradisional (2010:2), ia membagi musik tradisional menjadi dua yaitu musik tradisional rakyat dan musik tradisional klasik. Musik tradisional rakyat merupakan musik yang lahir dan diolah oleh masyarakat pedesaan, hidup dan berkembang ditengah-tengah rakyat, disukai oleh rakyat biasa, dan tersebar sampai ke rakyat jelata. Sedangkan musik tradisional klasik merupakan musik rakyat pilihan yang dikembangkan dipusat-pusat pemerintahan masyarakat lama, seperti di ibu kota kerajaaan, sehingga musik ini memiliki pembawaan yang lebih agung dan megah dibanding musik rakyat, musik ini merupakan ciptaan seseorang serta telah tertata dengan aturan yang berlaku.

Kesenian ma'ronggeng merupakan sebuah kesenian dengan memanfaatkan bambu atau yang dikenal sebagai barutung sebagai alat musiknya. Pada umumnya, bambu merupakan salah satu alat musik yang dimainkan dengan cara ditiup seperti yang dikatakan oleh Ali, M (1989) dalam (Buchary, 2008:19) menyatakan bahwa musik bambu adalah alat tiup yang mengeluarkan satu nada yang terbuat dari tabung bambu. Namun, berbeda dengan kesenian ma'ronggeng yang juga menggunakan bambu sebagai alat musiknya tapi dimainkan dengan cara yang berbeda yaitu di di hentakkan ke tanah.

Bambu atau barutung adalah salah satu hal yang tidak bisa dipisahkan dari masyarakat Desa Parombean sejak dulu hingga saat ini. Bambu memiliki berbagai fungsi dan peran penting untuk keberlangsungan hidup masyarakat di
Parombean, mulai dari ritual maupun sebagai alat yang digunakan untuk kehidupan sehari-hari pada umumnya. Kesenian ma'ronggeng atau ma'barutung lahir dari aktivitas keseharian masyarakat salah satunya yaitu pada saat masyarakat mengantri untuk mengambil air dengan menggunakan bambu atau barutung. Dalam kesenian ma'ronggeng, barutung yang digunakan sebagai alat musiknya terbagi ke dalam 3 jenis, yaitu lampa, pongke dan suke. Lampa dan pongke digunakan masyarakat ketika mengambil air di sumbernya sedangkan suke digunakan sebagai tempat untuk menyimpan garam yang sewaktu-waktu dapat dibunyikan ketika di desa tersebut dilanda bencana angin besar yang dipercayai oleh masyarakat Desa Parombean dapat melindungi desa dari berbagai kerusakan yang akan terjadi.

Tidak ada yang menyangka dari kebiasaan mengantri menunggu giliran mengambil air tercipta sebuah aktivitas masyarakat dengan menghentakhentakkan lampa dan pongke ke tanah, serta membunyikan suke ketika angin ribut datang, secara alami melahirkan musik yang belum terpahami maknanya. Mitos kedekatan barutung dan masyarakatnya menjadi inspirasi lahirnya kesenian ma'ronggeng atau ma'barutung. Inspirasi tersebut menjadi ide gagasan untuk menggabungkan bunyi dari ketiga barutung menjadi sebuah kesenian. Sejak saat itu, kesenian ma'ronggeng terus berkembang yang awalnya hanya terdiri dari 1 kelompok namun pada saat ini sudah terbentuk 3 kelompok kesenian di Desa Parombean yaitu, kelompok barutung eran langi', barutung bunga mendoe, dan satu kelompok yang belum memiliki nama karena usia terbentuknya masih terbilang muda.

Setiap kelompok tidak membatasi jumlah anggota yang bergabung dalam kelompoknya. Namun, ketika 
ma'ronggeng dipentaskan, maksimal anggota yang ikut tampil hanya 30 orang. Salah satu alasan mengapa hanya 30 orang saja yang boleh ikut dalam pementasan yaitu keterbatasan kostum dan masalah transportasi mengingat jarak antara satu dusun ke dusun lainnya di Desa Parombean sangat berjauhan. Selain kedua alasan di atas, terkadang orang yang memanggil kelompok kesenian ma'ronggeng di acaranya, telah membicarakan sebelumnya dengan ketua kesenian ma'ronggeng untuk membatasi jumlah pemain karena persoalan meminimalisir biaya yang akan dikeluarkan.

Zaman modernisasi seperti teknologi yang semakin berkembang kini membuat masyarakat bahkan di pedesaan dengan mudah dapat mengakses berbagai macam hal di sosial media yang sifatnya menghibur sehingga hal-hal tersebut dapat mempengaruhi ketertarikan dan menjadi ancaman punahnya berbagai kesenian tradisional. Namun, berbeda halnya dengan kesenian ma'ronggeng di Desa Parombean yang masih berusaha dipertahankan dan dijaga keberadaannya. Hal itu dapat dilihat dari inisiatif para pelaku kesenian ma'ronggeng yang selalu mengikutsertakan remaja bahkan anakanak dalam pertunjukannya sehingga jumlah kelompok dari kesenian ma'ronggeng semakin bertambah meski perkembangannya hanya dalam wilayah Kecamatan Curio khususnya Desa Parombean. Walaupun kesenian ma'ronggeng hanya berkembang di Desa Parombean namun besar harapan masyarakat agar kesenian ma'ronggeng bisa lebih dikenal masyarakat diluar wilayah Desa Parombean dengan lebih sering di tampilkan di acara-acara di Kabupaten Enrekang agar keberadaannya di zaman modernisasi seperti saat ini tetap terjaga dan tidak mengalami pergeseran.

Sejalan dengan pemaparan diatas, Alvin L. Betrand ( dalam Taneko 1993:139) menyatakan bahwa proses awal dari pergeseran di dalam masyarakat adalah karena komunikasi dan dengan demikian menyangkut masalah penyebarluasan gagasan-gagasan, ide-ide, dan keyakinan-keyakinan maupun hasilhasil budaya yang bersifat fisik. Prinsip efisiensi dan efektivitas sebagai asas dari teknologi modern telah merasuki semua aspek kehidupan manusia, sehingga kecenderungan untuk memilih berbagai produk barang dajn jasa selalu dalam pertimbangan yang serba efisien dan efektif. Maka tidak mengherankan jika prinsif efisiensi dan efektifitas pada akhirnya membudidaya dimana-mana sebagai pengaruh dari rutinitas yang terjadi.

\section{Fungsi Kesenian Ma'ronggeng di Desa Parombean Kabupaten Enrekang}

Kesenian merupakan sebuah elemen yang penting dalam kehidupan manusia. Sejak dahulu kala kesenian tradisional sudah memegang peranan dalam beberapa fungsi berdasarkan jenisnya. Berdasarkan pengertiannya, kesenian tradisional merupakan suatu karya yang diciptakan melalui ide/gagasan yang memiliki nilai estetika dan mampu membangkitkan perasaan penikmatnya. Seperti kesenian tradisional pada umumnya, kesenian ma'ronggeng juga merupakan sebuah kesenian yang lahir dan berkembang di Desa Parombean yang memiliki fungsi berdasarkan kebiasaan dan adat-istiadat yang diwariskan nenek moyang sejak dulu. Adapun fungsi dari kesenian ma'ronggeng adalah sebagai berikut :

a. Sebagai fungsi hiburan

Kesenian ma'barutung atau kesenian ma'ronggeng memiliki fungsi sebagai fungsi hiburan. Sejak dahulu ketika bambu atau barutung yang disebut pongke dan lampa digunakan untuk mengambil air, menjadi salah satu penghibur ditengah antrian yang lama saat menunggu hingga giliran tiba. Setelah dikenal sebagai sebuah 
Hamrin; Angraeni. Kesenian Ma'ronggeng Di Desa Parombean Kabupaten Enrekang

kesenian tradisional, ma'ronggeng kini memiliki fungsi yang bertujuan untuk menghibur masyarakat Parombean yang mayoritas penduduknya berpenghasilan sebagai petani saat setelah melakukan aktivitas di sawah. Selain itu kesenian ma'ronggeng menjadi media hiburan bagi orangorang yang menjadi bagian dari pertunjukannya maupun bagi masyarakat yang menjadi penontonnya.

b. Sebagai fungsi pengintegrasian masyarakat

Merriam dalam bukunya The Antropologhy of Music (1964: 218) menyatakan ada 10 fungsi dari musik salah satunya adalah sebagai fungsi pengintegrasian masyarakat. Sebuah kesenian yang dimainkan secara bersama-sama secara alami akan menghasilkan sebuah keakraban dan kebersamaan baik dari setiap pelaku keseniannya, maupun bagi setiap penonton yang hadir. Begitu pula dengan masyarakat di Desa Parombean yang memiliki nilai kebersamaan yang tinggi. Hal itu disebabkan karena baik pelaku dari kesenian ma'ronggeng maupun penonton, saling menyatu ketika kesenian ma'ronggeng di pertunjukkan.

\section{c. Sebagai fungsi ritual}

Jauh sebelum masyarakat di Desa Parombean mengenal islam, bambu atau barutung sudah dijadikan sebagai media penghubung dalam penolak bala kepada dewata. Di Desa Parombean, ma'tola bala diartikan penolakan terhadap bencana. Ma'tola dalam bahasa Indonesia adalah menolak sedangkan bala adalah bencana. Ma'tola bala merupakan tradisi masyarakat Desa Parombean yang hingga saat ini masih tetap di laksanakan. Bambu digunakan dalam ritual ma'tola bala ketika bencana angin besar melanda Desa Parombean.
Kini, ketika barutung dijadikan sebuah kesenian, namun masyarakat tidak melupakan fungsi awalnya. Mereka hingga saat ini masih menggunakan kesenian ma'barutung dalam setiap ritual menolak bala. Sejalan dengan fungsinya sebagai fungsi ritual, Soedarsono 1999 : 1 - 2 mengatakan bahwa penciptaan suatu karya seni selalu memiliki tujuan. Secara garis besar tujuan itu bisa dikelompokkan menjadi tiga, yaitu : (1) seni untuk tujuan ritual: (2) seni untuk tujuan persentasi estetis: dan (3) seni sebagai hiburan pribadi

\section{d. Sebagai fungsi komunikasi}

Sejak dahulu, barutung menjadi media komunikasi kepada Tuhan sebagai maha pencipta dengan harapan masyarakat dan Desa Parombean selalu dalam kebaikan. Namun kini, setelah menjadi sebuah kesenian, ma'ronggeng atau ma'barutung tidak hanya dijadikan sebagai media komunikasi kepada Tuhan, tapi ketika suatu acara dilangsungkan di Desa Parombean, hanya dengan mendengar suara khas dari bunyi barutung dalam kesenian ma'ronggeng, orang-orang dengan mudah akan tau ada sebuah hajatan yang sedang berlangsung. Seperti yang dikatakan oleh Merriam dalam bukunya The Antropologhy of Music (1964 : 218) bahwa musik memiliki fungsi komunikasi yang berarti bahwa senua musik yang berlaku disuatu daerah kebudayaan mengandung isyarat - isyarat tersendiri yang hanya diketahui oleh masyarakat pendukung kebudayaan tersebut.

\section{KESIMPULAN DAN SARAN \\ A. Kesimpulan}

Berdasarkan uraian pada bab sebelumnya yang menyajikan hasil penelitian dan pembahasan dari kesenian ma'ronggeng di Desa Parombean Kabupaten Enrekang, maka hasil penelitian tersebut dapat 
disimpulkan dalam sebuah kesimpulan sebagai berikut :

\section{Latar belakang kesenian ma'ronggeng di Desa Parombean Kabupaten Enrekang}

Kesenian ma'ronggeng merupakan sebuah kesenian yang pada awalnya dikenal dengan kesenian ma'barutung karena media yang digunakan sebagai alat musiknya adalah bambu atau barutung. Kesenian ma'ronggeng lahir dan berkembang di tengah-tengah masyarakat Desa Parombean. Jauh sebelum islam masuk di Parombean, barutung atau bambu yang biasa disebut suke oleh masyarakat sekitar, digunakan sebagai media penghubung dalam ritual penolak bala kepada dewata. Barutung yang hadir pada setiap sendi kehidupan masyarakat Parombean, secara alami mengekspresikan karya kesenian yang menjadi kultur dalam masyarakatnya.

Sejarah kesenian ma'ronggeng berawal dari kebiasaan masyarakat sekitar yang mengantri menunggu giliran mengambil air pada satu-satunya sumber mata air di Desa Parombean. Aktivitas ketika menunggu air adalah menghentakhentakkan bambu panjang yang disebut lampa dan pongke.

Dalam bahasa Parombean yang kemudian menimbulkan ide dan gagasan untuk menjadikan sebuah kesenian tradisional. Lampa, pongke, dan suke digabungkan sehingga menghasilkan bunyi khas bambu yang kemudian dinamai dengan kesenian ma'ronggeng atau ma'barutung.

Keterbatasan pendidikan tidak menjadi penghalang bagi seniman tradisional Parombean untuk terus belajar dari kearifan lokal. Proses regenerasi terus berrjalan sejak awal anak-anak sudah diperkenalkan dan dididik untuk mengenal kesenian ma'ronggeng atau ma'barutung. Konsep pelestarian nilai-nilai budaya yang tumbuh secara alami pada masyarakat Parombean, menjadi kekuatan besar yang lahir dari nurani masing-masing masyarakatnya dalam bingkai mitos bambu dengan berbagai simbol-simbil kearifan.

\section{Fungsi kesenian ma'ronggeng di Desa Parombean Kabupaten Enrekang}

Kesenian ma'ronggeng di Desa Parombean Kabupaten Enrekang terbagi kedalam 4 fungsi, yaitu fungsi hiburan, fungsi ritual, fungsi pengintegrasian masyarakat, dan fungsi komunikasi. Dikatakan sebagai fungsi hiburan karena kesenian ma'ronggeng menjadi media penghibur baik pagi para pelaku keseniannya maupun bagi masyarakat penontonnya yang capek usai seharian beraktivitas di sawah maupun di kebun. Rasa capek masyarakat di Desa Parombean seketika akan hilang saat menikmati kesenian ma'ronggeng karena rasa capek mereka akan tergantikan dengan rasa bahagia.

Dikatakan sebagai fungsi ritual karena sejak dulu barutung sudah digunakan dalam ritual penolak bala kepada dewata. Setelah menjadi kesenian, ma'barutung atau ma'ronggeng masih difungsikan sebagai ritual ketika bencana angin besar datang di Desa Parombean. Dikatakan sebagai fungsi pengintegrasian masyarakat karena kesenian ma'ronggeng telah membuat masyarakat di Desa parombean memiliki jiwa kebersamaan dan keakraban yang tinggi. Hal itu bermula ketika masyarakat yang hadir sebagai penonton menyatu dengan para pelaku kesenian ma'ronggeng saat pertunjukan sedang berlangsung.

Fungsi komunikasi merupakan salah satu fungsi dari kesenian ma'ronggeng. Sejak dulu dari fungsinya sebagai fungsi ritual, kesenian ma'ronggeng menjadi media komunikasi atau media penghubung masyarakat Desa Parombean dengan yang Maha Pencipta untuk selalu dalam lindunganNya ketika bencana datang. Terlepas dari fungsinya sebagai fungsi komunikasi kepada Tuhan, saat acara dilangsungkan di Desa Parombean, hanya dengan mendengar suara khas dari bunyi barutung dalam kesenian ma'ronggeng, 
Hamrin; Angraeni. Kesenian Ma'ronggeng Di Desa Parombean Kabupaten Enrekang

orang-orang dengan mudah akan tau ada sebuah hajatan yang sedang berlangsung.

\section{B. Saran-saran}

Dari hasil pemaparan dalam penelitian ini, penulis dapat memberikan saran sebagai berikut :

1. Agar diupayakan kelengkapan literatur oleh perpustakaan Fakultas Seni dan Desain Universitas Nrgeri Makassar, tentang musik tradisional yang ada di Sulawesi Selatan.

2. Agar diupayakan kelengkapan literatur oleh perpustakaan Fakultas Seni dan Desain Universitas Nrgeri Makassar, tentang musik tradisional yang ada di Sulawesi Selatan.

3. Kesenian ma'ronggeng atau ma'barutung harus lebih diketahui, dijaga, dan dilestarikan sebagai aset budaya di Kabupaten Enrekang.

4. Kesenian-kesenian tradisional di Sulawesi Selatan khususnya di Kabupaten Enrekang alangkah baiknya jika dijadikan sebagai sarana pendidikan dan rutin di tampilkan atau di perlombakan untuk menghindari kepunahan di zaman modernisasi yang semakin berkembang.

5. Kepada instansi yang terkait baik lembaga pemerintahan maupun lembaga non pemerintahan untuk senantiasa proaktif dan menggairahkan warga masyarakat yang dipimpinnya untuk mencintai dan menghargai kebudayaan daerah dengan mengadakan acara-acara yang bernansa budaya seperti pekan budaya ataupun festival kebudayaan daerah

\section{DAFTAR RUJUKAN}

Adhi, Ramdhan. 2010. Mengenal Seni Musik Tradisional. Penerbit: PT. Wacana Gelora Cipta, Bandung

Batara Randa, Ika Mustika. 2016. Musik Bambu (Bas) Dalam Acara Pesta Panen di Masyarakat Desa Tallung Ura' Kabupaten
Enrekang. Skripsi S-1. Makassar: Universitas Negeri Makassar.

Buchary, Soekarno. 2008. Musik Bass di Kecamatan Baraka, Kabupaten Enrekang.

Depdikbud. 1988. Kamus Besar Bahasa Indonesia. Jakarta: Balai Pustaka.

Gunawan, Imam. 2015. Metode Penelitian Kualitatif; Teori dan Praktek. Penerbit: PT. Bumi Aksara, Jakarta

Ibrahim. M.A. 2018. Metode Penelitian Kualitatif : Panduan Penelitian Beserta Contoh Proposal Kualitatif. Penerbit: PT. Alfabeta, Bandung

Irianto, 2017. Kesenian Tradisional Sebagai Sarana Strategi Kebudayaan di Tengah Determinasi Teknologi Komunikasi. Jurnal FIB Universitas Diponegoro, Vol 12, No. 1, Februari 2017, hal 91

Maryami, Enok. 2002. Antropologi Untuk Sekolah Menengah Umum. Bandung: Graffindo Media Pratama

Nashar, Fauzan Rikza. 2017. "Mempertahankan tradisi, Melestarikan Budaya" 9 Kajian Historis dan Nilai Budaya Lokal Kesenian Terebang Gede di Kota Serang). Jurnal Candrasangkala, Vol. 3, No. 1, 2017

Patadungan, 1938. Teori Musik 1. Makassar : Perpustakaan Seni FSD UNM

S. Suharto, Fakhturrohman Ali. 2017. Bentuk Musik dan Fungsi Kesenian Jamjaneng Grup " Sekar Arum “ DI Desa Panjer Kabupaten 
Jurnal Pakarena,Volume 3 Nomor 2, Desember 2018, hlm 1-13

Kebumen. Jurnal Seni Musik, Tahari, Muhammad. 2018. Pengembangan Vol. 6, No. 1, Juli 2017

Sugiyono. 2015. Metode Penelitian Kuantitatif, Kualitatif dan $R \& D$. Bandung: PT. Alfabeta

Sugiyono. 2017. Metode Penelitian Kuantitatif, Kualitatif dan $R \& D$. teori dan metode untuk ilmuilmu penciptaan dan pengkajian seni ( makalah ). Medan. Universitas Negeri Medan

Tyas Andijaning, Hartaris. 2006. Seni Musik Bandung: PT. Alfabeta

SMA Kelas 1, PT Gelora Aksara 